\title{
Dried Rum Distillery Stillage in Broiler Rations ${ }^{1,2}$
}

\author{
Francisco B. González, Paul F. Randel and Manuel Soldevila ${ }^{3}$
}

\begin{abstract}
In two experiments, each employing 200 hybrid chicks, dried stillage levels of $0,10,20$ and $30 \%$ were compared in rations based mainly on ground maize, soybean meal and fishmeal, and theoretically equicaloric and isonitrogenous. In experiment 1, chicks were fed starter rations (20.3-21.9\% CP) from 1 day until 4 weeks of age, and then grower rations (15.7-16.6\% CP) until marketing age at 9 weeks. The chicks spent the first 2 weeks in a battery brooder and thereafter were in pens of 20 each on a bedded floor. Mean final liveweights for the respective rations were 2446,2341, 1614 and $1223 \mathrm{~g}$, with $10 \%$ stillage not significantly different, but the $20 \%$ and $30 \%$ stillage treatments inferior to the control $(P<.01)$. Twenty-two chicks died, mostly during the first 2 weeks, but apparently not because of the experimental rations. The respective feed efficiencies (liveweight gain/feed intake) over the 9 weeks of test were $.46, .47, .34$ and .29 . A saving of other feed inputs was achieved without loss of efficiency by using $10 \%$ stillage, whereas the higher levels were inefficient. In experiment 2 all the chicks were raised to 5 weeks of age on a ration without stillage. The same grower rations as in experiment 1 were fed from 5 to 9 weeks. Mean final liveweights were 2106, 2098, 1968 abd $1628 \mathrm{~g}$, with the same significant differences among treatments as previously. The feed efficiencies during the 4 weeks of test were $.41, .38, .37$ and .25 , with only the $30 \%$ stillage inferior to the control ( $P$ $<.01$ ). The saving of other feed due to the use of stillage was less at the $10 \%$ level but more at the $20 \%$ than in experiment 1 . In neither experiment did the inclusion of stillage make the rations unacceptable to the chicks. There was a direct relation between stillage level and daily feed intake as a percentage of liveweight. Sanitary conditions worsened due to black and watery excreta at successive stillage levels. Ten percent dried stillage, or possibly slightly higher in the final stages of growth, could be used in broiler rations as one non-polluting method of stillage disposal with only a minimal reduction in animal productivity.
\end{abstract}

\section{INTRODUCTION}

The search for non-polluting and preferably beneficial means of disposal of stillage (cane-molasses-distiller's solubles) is a pressing problem in Puerto Rico, where the rum industry is very important and where environmental protection is a growing concern. One solution, at least to part of the problem, might be the use of stillage for feeding various classes of livestock. The island's poultry industries, which are expanding and consuming ever larger quantities of imported feed, might benefit from the utilization of stillage as feed. In order to evaluate this possibility, information on the nutritive value of the local stillage for poultry is essential.

${ }^{\prime}$ Manuscript submitted to Editorial Board January 2, 1979.

${ }^{2}$ Data taken from a MS thesis submitted by the senior author to the Graduate School of the Mayagüez Campus, University of Puerto Rico.

${ }^{3}$ Former graduate student and Nutritionists, Agricultural Experiment Station, College of Agricultural Sciences, Mayagüez Campus, University of Puerto Rico, Río Piedras, P.R. 
Two previous studies were conducted with laying hens, the first involving two separate experiments in which individually caged birds received rations containing from 0 to $30 \%$ of dried stillage ${ }^{4}$. The rations were isonitrogenous, but not equicaloric, and the energy-diluting effect of the high-ash stillage, in detriment to the feed conversion efficiency, was manifest at all levels of inclusion in the diet. Thus, even though levels of up to $20 \%$ stillage gave satisfactory production, nothing was gained in the substitution of stillage for other feeds.

In a subsequent experiment the rations employed from 0 to $35 \%$ of dried stillage and were made theoretically equicaloric by the addition of animal fat ${ }^{5}$. A $15 \%$ stillage ration resulted in no loss of feed efficiency relative to the control and only a slight, not significant, decrease in laying rate. Stillage levels higher than 15\% resulted in poorer production and caused sanitation problems due to the black and watery excreta. However, no serious toxicity could be ascribed to the stillage, even at the highest levels, in either study.

The present study was the first by the authors on the use of stillage in rations for broilers.

\section{MATERIALS AND METHODS}

During the spring and summer of 1976 two successive experiments were conducted at the Lajas Substation, with broilers of the Hobbard and Hobbard Line to compare levels of $0,10,20$ and $30 \%$ of dried stillage in the ration.

Experiment 1 was divided into two phases. Phase A began with dayold chicks and lasted for 2 weeks. Four groups of 50 birds each, selected at random, were housed in separate compartments of a battery brooder. They were exposed to artificial light during the first 5 days and received feed and water ad libitum. One group was assigned to each of four levels of stillage. The starter rations shown in table 1 were formulated to meet the $\mathrm{NRC}^{6}$ nutrient requirements.

The stillage was obtained from commercial distilleries and processed at the Rum Pilot Plant of the Agricultural Experiment Station in Rio Piedras. Being very hygroscopic in dried form, the stillage was shipped and stored in plastic bags within sealed metal drums. As received it contained many large particles; therefore it was ground through a 2-mm

${ }^{4}$ Diaz-Medina, M. and P.F. Randel, 1978. Dried rum distillery stillage in laying rations, J. Agri. Univ. P.R. 62(2):149,-55.

${ }^{5}$ Soldevila, M. and R. Irizarry, 1977. Influence of dried rum distillery slops in diets for White Leghorn hens on laying rate, feed conversion, and egg size and quality, J. Agri. Univ. P.R. 61(4):465,-9.

${ }^{6}$ NRC. 1971. Nutrient requirements of poultry, 6th ed, Nat. Acad. Sci. , Washington, D.C. 
TABLE 1.-Percentage formula and chemical composition of the experimental rations

\begin{tabular}{|c|c|c|c|c|c|c|c|c|}
\hline \multirow{2}{*}{ Stillage level } & \multicolumn{4}{|c|}{ Starter rations } & \multicolumn{4}{|c|}{ Grower rations } \\
\hline & 0 & 10 & 20 & 30 & 0 & 10 & 20 & 30 \\
\hline \multicolumn{9}{|l|}{ Formula } \\
\hline Ground yellow maize & 66.0 & 51.9 & 37.8 & 23.7 & 78.0 & 63.9 & 48.9 & 34.0 \\
\hline Soybean meal ( $43 \% \mathrm{CP})$ & 19.0 & 21.2 & 23.4 & 25.6 & 10.0 & 11.8 & 13.5 & 15.3 \\
\hline Tunafish meal $(50 \% \mathrm{CP})$ & 11.0 & 11.0 & 11.0 & 11.0 & 10.0 & 10.0 & 10.0 & 10.0 \\
\hline Dehydrated rum stillage & 0 & 10.0 & 20.0 & 30.0 & 0 & 10.0 & 20.0 & 30.0 \\
\hline $\begin{array}{l}\text { Vitamin-mineral premix with con- } \\
\text { mon salt }\end{array}$ & 2.0 & 2.0 & 2.0 & 2.0 & 1.3 & 1.3 & 1.3 & 1.3 \\
\hline Dried skim milk & 2.0 & 2.0 & 2.0 & 2.0 & 0 & 0 & 0 & 0 \\
\hline Animal fat & 0 & 1.9 & 3.8 & 5.7 & 0 & 3.0 & 6.1 & 9.2 \\
\hline \multicolumn{9}{|l|}{ Chemical composition } \\
\hline Dry matter & 92.6 & 92.4 & 93.9 & 93.7 & 94.2 & 94.6 & 93.2 & 94.7 \\
\hline Crude protein & 21.9 & 21.8 & 20.6 & 20.3 & 16.0 & 15.8 & 16.6 & 15.7 \\
\hline Productive energy $(\mathrm{Mcal} / \mathrm{kg})^{\prime}$ & 2.12 & 2.12 & 2.13 & 2.15 & 2.26 & 2.32 & 2.38 & 2.45 \\
\hline Ash & 9.25 & 9.15 & 14.19 & 17.58 & 6.54 & 9.74 & 13.71 & 17.57 \\
\hline Calcium & .96 & .99 & 1.05 & 1.07 & .66 & .94 & 1.11 & 1.33 \\
\hline Phosphorus & .48 & .51 & .48 & .54 & .48 & .42 & .48 & .50 \\
\hline Potassium & .57 & .60 & 2.52 & 3.43 & .41 & 1.36 & 2.32 & 3.46 \\
\hline Magnesium & .31 & .24 & .71 & .86 & .26 & .37 & .58 & .76 \\
\hline
\end{tabular}

' Values estimated from published tables, assuming that the dry matter of stillage is equal to that of cane molasses in productive energy content. 
screen prior to incorporation into the rations. Immediately after mixing, the rations were stored in plastic bags within sealed drums, but even this procedure did not completely prevent the absorption of moisture by the rations containing high levels of stillage.

At the start of Phase B the 184 surviving 2-week-old chicks were divided at random within treatments into 20 groups ( 4 groups of 10 each and a 5 th group of variable number in each treatment). At this time the birds were moved to a poultry house with 20 compartments $(3.1 \times 2.5 \mathrm{~m})$, where they were kept on the floor, bedded with sugarcane bagasse. Each pen had an automatic watering cup and a hanging feeder, in which sufficient feed was placed to allow ad libitum consumption. At 4 weeks of age the chicks were switched to grower rations containing the same stillage levels (table 1), which they received until the end of the experiment. Liveweight and feed intake data were recorded by group at 2 -week intervals, except for the final 8th to 9 th week.

Experiment 2 was preceded by a preliminary period, lasting from 1 day to 5 weeks of age, in which only one treatment, without stillage feeding, was employed. The purpose of this period was to obtain birds as uniform as possible for use in testing stillage in the ration during only the final phase prior to marketing.

Throughout both experiments feed samples were taken for determination of dry matter content by oven drying and of proximate components and major minerals by methods of $\mathrm{AOAC}^{7}$. The data pertaining to liveweight, feed intake (both absolute and as percentage of liveweight) and feed efficiency were subjected to analysis of variance and multiple range tests.

\section{RESULTS AND DISCUSSION}

\section{EXPERIMENT 1}

The over-all mean initial liveweight at one day of age was $38 \mathrm{~g}$. During the 2 weeks that the chicks were confined to the brooder, the number per treatment was reduced by mortality to $45,50,43$ and 46 in the control, $10 \%, 20 \%$ and $30 \%$ stillage treatments, respectively. The corresponding mean daily gains in liveweight per chick were 13.3, 10.7, 7.2 and $5.6 \mathrm{~g}$. It was also noted that the rate of feather development varied inversely with the level of stillage in the ration. Thus, at this early stage all additions of stillage had an adverse effect on growth, though the statistical significance thereof could not be established due to the lack of treatment replication. However, daily feed intake was not much affected, even by the high levels

AOAC. 1970. Official Methods of Analysis. 11th ed. Ass. Offic. Agr. Chemists. Washington, D.C. 
TABLE 2.-Mean liveweight and daily feed intake per chick, efficiency of feed utilization for gain and coefficients of variation among pens

\begin{tabular}{cccccc}
\hline Stillage level & 0 & 10 & 20 & 30 & CV \\
\hline
\end{tabular}

Experiment I

Phase A (initial) (2wk.)

Phase B ( 4 wk.) (6wk.)

(8 wk.)

Liveweight (kg)

(9 wk.)

Experiment II

(5 wk.)

(7 wk.)

(9wk.)

Experiment I

Phase A (0-2 wk.)

Phase B (2-4 wk.)

(4-6 wk.)

(6-8 wk.)

(8-9 wk.)

Experiment II

$(5-7$ wk.)

(7-9 wk.)

Experiment I

Phase A (0-2 wk.)

Phase B (2-4 wk.)

(4-6 whi)

(6-8 wk)

(8-9 wk.)

Experiment II

$$
\text { (5-7 wk.) }
$$

(7-9 wk.)

$\begin{array}{cc}.035 & .041 \\ .221^{\mathrm{a} 1} & .191^{\mathrm{b}} \\ .597^{\mathrm{a}} & .581^{\mathrm{a}} \\ 1.263^{\mathrm{a}} & 1.164^{\mathrm{b}} \\ 1.867^{\mathrm{aA}} & 1.707^{\mathrm{B}} \\ 2.446^{\mathrm{a}} & 2.341^{\mathrm{a}}\end{array}$

.035
$.135^{\mathrm{c}}$
$.389^{\mathrm{b}}$
$.878^{\mathrm{c}}$
$1.358^{\mathrm{b}}$
$1.614^{\mathrm{h}}$

$\begin{array}{rr}.042 & - \\ .120^{\mathrm{c}} & 5.04 \\ .277^{\mathrm{c}} & 7.47 \\ .616^{\mathrm{d}} & 4.75 \\ 1.063^{\mathrm{c}} & 7.73 \\ 1.223^{\mathrm{c}} & 7.20\end{array}$

$.972^{\mathrm{A}}$
$1.534^{\mathrm{A}}$

\section{$.984^{\mathrm{A}}$}

$1.544^{\mathrm{aA}}$

$.974^{\mathrm{A}}$

$1.457^{\mathrm{aB}}$

$1.005^{\mathrm{A}}$

$1.216^{\mathrm{b}}$

$2.106^{\mathrm{a}}$

$2.098^{\mathrm{a}}$

$1.968^{b}$

$1.628^{\circ}$

3.10

4.11

2.69

Feed consumption (kg)

$\begin{array}{llllr}.019 & .017 & .018 & .016 & - \\ .064^{\mathrm{A}} & .060^{\mathrm{A}} & .058^{\mathrm{A}} & .050^{\mathrm{A}} & 19.79 \\ .111^{\mathrm{a}} & .100^{\mathrm{ab}} & .092^{\mathrm{hC}} & .056^{\mathrm{A}} & 8.90 \\ .129^{\mathrm{A}} & .132^{\mathrm{A}} & .131^{\mathrm{A}} & .124^{\mathrm{A}} & 5.45 \\ .130^{\mathrm{ahA}} & .135^{\mathrm{a}} & .133^{\mathrm{abA}} & .116^{\mathrm{hB}} & 6.87\end{array}$

$\begin{array}{lllll}.100^{\mathrm{a}} & .109^{\mathrm{A}} & .102^{\mathrm{a}} & .065^{\mathrm{b}} & 11.20 \\ .114^{\mathrm{A}} & .113^{\mathrm{A}} & .120^{\mathrm{A}} & .100^{\mathrm{A}} & 14.48\end{array}$

Feed efficiency (liveweight gain/feed)

1 Means followed by one or more letters in common do not differ significantly at $\mathrm{P}<.01$ (lower case) or at $\mathrm{P}<.05$ (upper case).

of stillage (table 2). In feed efficiency (gain/feed), the $10 \%$ stillage treatment was only slightly inferior to the control (.67 vs. .64), whereas the $20 \%$ and $30 \%$ treatments were decidedly inferior (.37 and .36). Progressive staining of the chicks with black and watery excreta was obvious at increasing levels of stillage.

When the 20 groups were randomly formed to begin Phase B, there already existed significant differences $(\mathrm{P}<.01)$ among treatments in liveweight, the control (221 g) exceeding all others and the $10 \%$ stillage 
(191 g) surpassing the 20\% (135 g) and 30\% (120 g). The coefficient of variation (CV) among pens was $5 \%$ at this point (table 2).

During the first two weeks under the new housing arrangement, while the starter rations were still being fed, there were no mortality losses. The mean daily gains in liveweight during this period were 26.9, 27.9, 18.1 and $11.2 \mathrm{~g}$ for the four respective treatments. Mean liveweight at 4 weeks of age was not significantly different between the control $(597 \mathrm{~g})$ and the $10 \%$ stillage $(581 \mathrm{~g})$, but was lower $(\mathrm{P}<.01)$ with the $20 \%(389 \mathrm{~g})$ and $30 \%$ $(277 \mathrm{~g})$ stillage treatments. The $\mathrm{CV}$ in liveweight increased slightly to $7.5 \%$ at 4 weeks (table 2). Feed intake from 2 to 4 weeks was not much affected by stillage in the rations; however, there was high variability among pens. The over-all CV was $19.8 \%$ (table 2), but within individual treatments the highest CV was $39.1 \%$ at the $20 \%$ stillage level and the lowest $5.1 \%$ at the $10 \%$ level. During this interval the best feed efficiency (.46) was obtained with the $10 \%$ stillage treatment; that of the control (.42) did not differ significantly, but the efficiencies of .34 and .22 for the $20 \%$ and $30 \%$ stillage treatments were significantly lower $(\mathrm{P}<.01)$. Here also there was much variability among pens, especially at the $20 \%$ and $30 \%$ stillage levels, where the respective CV values were $26.0 \%$ and $27.1 \%$.

During the 2 weeks following the switch to the grower rations six chicks died, two among the controls and four among those fed $30 \%$ stillage, reducing the total number of survivors to 178. Liveweight gains averaged $47.5,41.7,34.9$ and $24.2 \mathrm{~g}$ daily on the four rations during this interval. At 6 weeks, coinciding with the lowest CV in liveweight (4.8\%), the advantage of the control over the $10 \%$ stillage treatment (1,263 vs. $1,164 \mathrm{~g})$ reverted to significance $(\mathrm{P}<.01)$, after having been not significant 2 weeks earlier. From 4 to 6 weeks the absolute feed intake was depressed $(\mathrm{P}<.01)$ in the chicks fed $30 \%$ stillage ( $56 \mathrm{~g} /$ day) and to a lesser degree in those fed $20 \%$ stillage ( $92 \mathrm{~g} /$ day), but this can be ascribed to their smaller body size rather than to poor acceptability of the rations. When daily feed intakes for this period are expressed as a percentage of liveweight, the values for the four rations are 8.76, 8.60, 10.47 and 9.03, with no significant differences among them. Furthermore, the CV in absolute feed intake $(8.9 \%)$ was less than half that during the preceeding period (table 2). In feed efficiency from 4 to 6 weeks, neither the $10 \%$ (.44) nor the 20\% (.36) stillage treatment differed significantly from the control (.42), though $30 \%$ stillage was less $(\mathrm{P}<.01)$ efficient $(.31)$. The C.V. in this criterion also declined relative to the preceeding period (table 2 ).

No broilers beyond 6 weeks of age died. The mean daily increments in liveweight from 6 to 8 weeks were $43.2,38.8,34.3$ and $31.9 \mathrm{~g}$ for the respective treatments. In liveweight at 8 weeks of age, the control (1867 g) was superior $(\mathrm{P}<.05)$ to the $10 \%$ stillage treatment $(1707 \mathrm{~g})$ and $(\mathrm{P}$ 
$<.01$ ) to the $20 \%$ and $30 \%$ stillage (1358 and $1063 \mathrm{~g}$ ). Mean absolute feed intakes from 6 to 8 weeks ranged from $132 \mathrm{~g}$ for the $10 \%$ stillage treatment to $124 \mathrm{~g}$ for the $30 \%$ stillage and the overall C.V. was only $5.4 \%$. However, in all treatments the feed efficiency declined relative to the previous period (table 2).

During the final interval, from 8 to 9 weeks, the mean daily gains in the control and $10 \%$ stillage treatments jumped to $82.6 \mathrm{~g}$ and $90.6 \mathrm{~g}$, respectively, and the downward trend in feed efficiency in these treatments was reversed, but the chicks fed $20 \%$ and $30 \%$ stillage gained only $36.5 \mathrm{~g}$ and $22.8 \mathrm{~g}$ per day and essentially repeated their feed efficiencies of the previous period (table 2). The final liveweights were inversely related to the level of stillage in the ration, though that of the $10 \%$ stillage treatment $(2341 \mathrm{~g})$ did not differ significantly from the control $(2446 \mathrm{~g})$. The means of $1614 \mathrm{~g}$ and $1223 \mathrm{~g}$ for the $20 \%$ and $30 \%$ stillage treatments were inferior $(\mathrm{P}<.01)$. From 8 to 9 weeks the absolute feed intake was similar in all treatments, except the $30 \%$ stillage (116 g/day), which was lower $(\mathrm{P}<.01)$. However, the relative feed intakes (as a percentage of liveweight) varied directly with the level of stillage in the rations (5.33, $5.78,8.25$ and 9.48).

During the periods comprising the first 4 weeks and that from 4 to 9 weeks when the starter and grower rations were fed, respectively, the total increases in liveweight were $562 \mathrm{~g}$ and $1849 \mathrm{~g}$ in the control chicks and $540 \mathrm{~g}$ and $1760 \mathrm{~g}$ in those fed $10 \%$ stillage. Since the latter figures represent 96\% and 95\% of the former, the effect on growth of including this level of stillage in the ration was negligible. The cumulative feed efficiency during the 9 weeks of this experiment was .46 for the control and .47 for the $10 \%$ stillage treatment. The main rationale for feeding stillage is to save other feed ingredients, which are mostly imported and expensive. A saving of this sort was realized, since per gram of nonstillage feed inputs the gain in liveweight was $.52 \mathrm{~g}$ for the $10 \%$ stillage treatment, as opposed to $.46 \mathrm{~g}$ when no stillage was fed. At the two higher levels the stillage markedly reduced growth and feed efficiency. The overall liveweight gains of the chicks fed 20\% and 30\% stillage (1579 $\mathrm{g}$ and $1181 \mathrm{~g}$ ) were equivalent to only $65 \%$ and $49 \%$, respectively, of that of the controls. Their cumulative feed efficiencies were .34 and .29 and their efficiencies exclusive of stillage .42 and .41.

\section{EXPERIMENT 2}

This experiment tested the same stillage levels as previously, but it was designed to determine whether the responses would be different if the chicks were not exposed to stillage feeding until after the critical early stages of life. When the 187 survivors, from 200 in the preliminary period, 
were randomly divided into 20 groups at 5 weeks, the mean initial liveweights were $972,984,974$ and $1005 \mathrm{~g}$ in the four respective treatments.

The respective daily liveweight gains from 5 to 7 weeks were 40.1, 39.9, 34.5 and $15.0 \mathrm{~g}$, which resulted in mean liveweights of 1534, 1544, 1457 and $1216 \mathrm{~g}$ at 7 weeks (table 2). At this point only the chicks fed $30 \%$ stillage weighed significantly less $(\mathrm{P}<.01)$ than the controls. During the second and final 2-week interval, the respective daily gains were 40.9, 39.6, 36.5 and $29.4 \mathrm{~g}$. Final liveweights at 9 weeks were 2106, 2098, 1968 and $1628 \mathrm{~g}$, both the $20 \%$ and $30 \%$, but not the $10 \%$, being inferior ( $\mathrm{P}$ $<.01)$ to the control. The CV in liveweight never exceeded $4.1 \%$ in this experiment (table 2). Total liveweight gains during the 4 weeks were $1134,1114,994$ and 623 , the latter three figures representing $98 \%, 88 \%$ and $55 \%$ of the control, respectively.

Feed intake did not show a definite trend with the level of stillage in the ration, except that $30 \%$ stillage resulted in lower $(\mathrm{P}<.01)$ intake from 5 to 7 weeks. Variability among pens in feed intake was high, as shown by the over-all $\mathrm{CV}$ of $11.2 \%$ and $14.5 \%$ in the two successive periods (table 2 ). Within the control treatment the corresponding values were only $1.7 \%$ and $4.0 \%$, in contrast to the treatments including stillage, which showed maxima of $12.8 \%, 23.5 \%$ and $16.8 \%$ at the three successive levels. Thus, the response in feed intake was erratic when the unaccustomed chicks were first exposed to stillage at 5 weeks of age. This suggests that an earlier age at first exposure to stillage (at a moderate level) would be preferable.

Feed efficiency tended to vary inversely with the level of stillage, though variability in this characteristic was also high, especially from 5 to 7 weeks (table 2). The $10 \%$ and $20 \%$ stillage treatments did not differ significantly from the control, whereas the $30 \%$ was inferior $(\mathrm{P}<.01)$. Over-all feed efficiencies during the 4 weeks of test were, respectively, $.41, .38, .37$ and .25 . The corresponding values for the conversion of nonstillage feed inputs were $.41, .42, .46$ and .36 . In this case rather little of other feeds was saved by the inclusion of $10 \%$ stillage, more being saved by using $20 \%$ stillage.

Both experiments demonstrated large losses of productivity due to feeding $30 \%$ stillage. Furthermore, the tendency of this ration to form a very hard mass upon exposure to atmospheric moisture and the black diarrhea in the chicks which consumed it, made this level of stillage totally impractical. This treatment did, however, serve to show that broilers will consume rations very high in stillage content and that this byproduct is of low toxicity, as shown in previous results with laying hens $(2,4)$.

The $20 \%$ stillage level was much less severe than $30 \%$, but still had a 
definite adverse effect on productivity when fed from an early age. Withholding the stillage until 5 weeks of age mitigated the adverse effect, but whether this improved the ability of the chicks to utilize $20 \%$ stillage later on is debatable. The growth rate with this ration from 6 to 9 weeks in experiment 1 was nearly identical to that from 5 to 9 weeks in experiment 2. The most notable improvement obtained in the latter case was a higher feed efficiency (.41) from 5 to 7 weeks, compared to .31 from 6 to 8 weeks previously, but that of experiment 2 declined to .33 from 7 to 9 weeks, while in experiment 1 it was .31 from 8 to 9 weeks. The $20 \%$ stillage ration can not be recommended for commercial use, although it is well tolerated and utilized fairly effectively by broilers beyond 2 weeks of age. The $10 \%$ stillage level, even when fed from an early age affected growth only slightly, but perhaps a lower level would be preferable during the first 2 weeks. No serious diarrhea was caused by $10 \%$ stillage. At this level, the feed efficiency tended to be equal to the control in experiment 1 , but somewhat inferior in experiment 2, in spite of the addition of fat to the stillage ration to equal the caloric content of the control. The loss of feed efficiency in experiment 2 , though not significant $(\mathrm{P}>.05)$, reduced the saving in other feed resources achieved by the utilization of stillage.

The level of stillage to be recommended would depend upon the objectives of the feeding operation. If the disposal of a maximum amount of stillage is of primary importance, in addition to obtaining nearly maximum growth, the $10 \%$ level appears to be a good alternative, and perhaps a level intermediate between $10 \%$ and $20 \%$ could be used in the later stages of the production cycle. If, however, the maximum growth and feed efficiency is essential, with the utilization of stillage being a secondary consideration, less than $10 \%$ in the ration would probably be needed and further research would be advisable to determine the most appropriate level.

\section{RESUMEN}

Se efectuaron dos experimentos, ambos con 200 polluelos híbridos, para comparar contenidos de mosto de destilería deshidratado de 0, 10, 20 y $30 \%$ en raciones, basadas principalmente en maíz molido y harinas de soya y de pescado, teóricamente isocalóricas e isonitrogenadas. En el experimento I se suplieron raciones de arranque (20.3 -21.9\% PC) desde el primer día hasta 4 semanas de edad y luego raciones de crecimiento (15.7 -16.6\% PC) hasta la edad comercial a las 9 semanas. Las aves se alojaron en una batería de pisos durante las primeras 2 semanas y luego en jaulas de 20 pollos cada una sobre piso con camada. Los pesos medios finales para las cuatro raciones fueron 2446,2341 , 1614 y $1223 \mathrm{~g}$, respectivamente, siendo el tratamiento con 10\% de mosto no diferente significativamente pero las de $20 \%$ y $30 \%$ de mosto 
fueron inferiores al testigo $(P<.01$ ). Hubo 22 bajas por mortalidad, mayormente durante las primeras 2 semanas, pero éstas, aparentemente, no fueron por causa de las raciones experimentales. Las respectivas eficiencias alimenticias (ganancia de peso vivo/consumo de alimento) durante las 9 semanas de prueba fueron .46, .47, .34 y .29. Se logró una economía en otros insumos alimentarios sin perjudicar la eficiencia, mediante el uso de 10\% mosto, mientras que los niveles mayores de éste no fueron tan beneficiosos.

En el experimento 2 todos los pollos se criaron hasta 5 semanas de edad con una ración sin mosto. De 5 a 9 semanas se suplieron las mismas raciones de crecimiento que en el experimento 1. Los respectivos pesos medios finales fueron 2106, 2098, 1968 y $1628 \mathrm{~g}$, habiendo las mismas diferencias significativas entre tratamientos que anteriormente. Las eficiencias alimenticias durante las 4 semanas de prueba fueron $.41, .38, .37$ y .25 , siendo únicamente el $30 \%$ de mosto inferior al testigo ( $P<.01$ ). La economía en otros insumos alimentarios debido al uso de mosto fue menor al 10\%, pero mayor al 20\% que en el experimento 1. Todas las raciones con mosto fueron bien aceptadas por las aves. Hubo una tendencia a mayor consumo diario como porcentaje del peso vivo a medida que aumentó el nivel de mosto en la ración. Las condiciones sanitarias se empeoraron progresivamente debido a la excreta negruzca y acuosa a mayores niveles de mosto. Se puede utilizar un $10 \%$ de mosto deshidratado, o possiblemente un nivel levemente mayor durante las últimas etapas de crecimiento, en raciones para pollos asaderos como método no contaminante de desechar el mismo, con tan solo una mínima reducción en la productividad animal. 